\title{
KAJIAN STATISTIK UKURAN BESAR BUTIR SEDIMEN DAN KAITANNYA DENGAN VARIABILITAS IKLIM MUSIMAN DAN TAHUNAN DI MUARA GEMBONG, TELUK JAKARTA
}

\section{STATISTICAL ASSESSMENT OF SEDIMENT GRAIN SIZE AND ITS RELATION WITH SEASONAL AND ANNUAL CLIMATE VARIABILITY IN MUARA GEMBONG, JAKARTA BAY}

\author{
Taufik R. Syachputra ${ }^{1}$, Ivonne M. Radjawane $^{1 *}$ dan Rina Zuraida ${ }^{2}$ \\ ${ }^{1}$ Program Studi Oseanografi, FITB-ITB, Bandung, 40132, Indonesia \\ ${ }^{2}$ Pusat Survei Geologi, Badan Geologi, Kementerian ESDM, Bandung, 40115, Indonesia \\ *E-mail: ivonne@ fitb.itb.ac.id
}

\begin{abstract}
Climate variability affects the properties of marine sediments. One of the sediment properties affected by climate is the grain size. This study is aimed to test the relation between sediment grain size and climate variability using sediment core GM01-2010-TJ22 that was acquired off Muara Gembong, which is part of Citarum river mouth. The samples were acquired in 2010 onboard RV. Geomarin I by Marine Geological Institute (MGI). Grain size analysis was conducted by Mastersizer 2000. The mean grain size is presented in time series for the 2001-2010 period. Then, the grain size sediment sample was correlated statistically with the seasonal (monsoon), annual, and interannual (El Niño/La Niña and Dipole Mode) phenomena. Data verification was conducted using secondary data of sea surface temperature from satellite images near the sediment sampling location and rainfall data in Bekasi. The verification result shows an increase in precipitation rate downriver of Citarum River followed by the decrease of sea surface temperature and larger grain size. The results using statistical test show that change of sediment sample's grain size in Muara Gembong have significant correlation with Multivariate of ENSO (El Niño Southern Oscillation) Index (MEI), Ocean Niño Index (ONI), Dipole Mode Index (DMI) and Australian Monsoon Index (AUSMI). This result shows that sediment grain size can potentially be used to identify climate variability in Jakarta Bay.
\end{abstract}

Keywords: dipole mode, ENSO, grain size, Jakarta Bay, monsoon, sedimentation

\begin{abstract}
ABSTRAK
Variabilitas iklim dapat mempengaruhi sifat sedimen yang terendapkan di dasar laut. Salah satu sifat sedimen yang dipengaruhi oleh iklim adalah besar butir. Penelitian ini bertujuan untuk menguji hubungan antara besar butir dengan variabilitas iklim menggunakan sampel core GM01-2010-TJ22 dari Muara Gembong, Teluk Jakarta, muara sungai Citarum. Sampel core diambil pada tahun 2010 dengan menggunakan Kapal Riset Geomarin I oleh Pusat Penelitian dan Pengembangan Geologi Kelautan (P3GL). Pengukuran besar butir dilakukan dengan menggunakan Mastersizer 2000. Hasil pengukuran ditampilkan dalam seri waktu dari tahun 2001 sampai 2010. Hasil analisis besar butir sampel sedimen dikorelasikan secara statistik dengan fenomena musiman (monsun), tahunan dan antar tahun (El Niño/La Niña dan Dipole Mode). Verifikasi data dilakukan dengan menggunakan data sekunder temperatur permukaan laut dari citra satelit di sekitar lokasi sampel dan data curah hujan di Bekasi. Hasil verifikasi menunjukkan bahwa peningkatan curah hujan di sekitar daerah hilir Sungai Citarum diikuti dengan penurunan temperatur permukaan laut dan peningkatan ukuran rata-rata besar butir. Hasil yang didapat dalam uji statistika menunjukkan bahwa perubahan ukuran besar butir sampel sedimen di Muara Gembong memiliki korelasi signifikan dengan Multivariate ENSO (El Niño Southern Oscillation) Index (MEI), Ocean Niño Index (ONI), Dipole Mode Index (DMI) dan Australian Monsoon Index (AUSMI). Hasil tersebut menunjukkan bahwa besar butir sedimen dasar laut potensial digunakan untuk mengetahui variabilitas iklim di sekitar Teluk Jakarta.
\end{abstract}

Kata kunci: besar butir, Dipole Mode, ENSO, monsun, sedimentasi, Teluk Jakarta 


\section{PENDAHULUAN}

Teluk Jakarta merupakan muara dari 13 sungai (Prartono et al., 2009), yang mana curah hujan di sekitar daerah aliran sungai (DAS) sungai-sungai tersebut diangkut menuju Teluk Jakarta. Input dari sungai tentu mempengaruhi volume air di sekitar Teluk Jakarta, dan dapat menyebabkan banjir dari arah Teluk Jakarta menuju daratan sekitarnya. Salah satu sungai penting yang bermuara di Teluk Jakarta adalah Sungai Citarum yang berhulu di daerah gunung Wayang (Kabupaten Bandung) dan bermuara di Muara Gembong, Bekasi di daerah Teluk Jakarta. DAS Citarum sendiri merupakan gabungan dari 19 aliran sungai (http://citarum.org/-tentang-kami/sekilascitarum/kondisi-fisik-dan-spasial.html).

Kondisi ini menyebabkan endapan di bagian timur Teluk Jakarta pada rentang waktu resen didominasi oleh endapan deltaik Citarum dan endapan laut dangkal (Rahardiawan et al., 2016).

Telah diketahui bahwa endapan sedimen dasar laut dapat digunakan sebagai salah satu parameter dalam mengkaji variabilitas iklim. Salah satu parameter yang telah digunakan adalah perubahan besar butir debu yang terbawa oleh angin (endapan eolian) untuk melakukan rekonstruksi arus masa lalu seperti yang diamati oleh LopezGonzalez et al. (2019) di Laut Alboran, Mediterania bagian barat. Hingga saat ini, belum ada penelitian yang mencoba menghubungkan besar butir sedimen dari perairan Indonesia dengan variabilitas iklim. Penelitian ini bertujuan untuk mengetahui hubungan antara besar butir sedimen dasar laut dan variabilitas iklim.

Moechtar (2011) menyimpulkan sejarah pembentukan interval pengendapan DAS Citarum berkaitan dengan perubahan iklim. Dalam penelitian ini akan dikaji korelasi variabilitas iklim di Teluk Jakarta dengan menggunakan core sedimen dasar laut. Sampel sedimen dari Teluk Jakarta diolah menggunakan analisis besar butir untuk melihat pengaruh dari variabilitas iklim terhadap kondisi oseanografi Teluk Jakarta. Iklim Teluk Jakarta dipengaruhi oleh faktor musim dan fenomena antara tahun seperti $E l$ Nino/La Nina dan Indian Ocean Dipole, karena itu variabilitas iklim yang akan ditinjau dalam penelitian ini berkaitan dengan pengaruh monsun dan fenomena antar tahun. Analisis ukuran besar butir akan digunakan untuk melihat variabilitas iklim yang dikorelasikan secara statistik dengan indeks musim Australian Monsoon Index (AUSMI) dan indeks antar tahun Multivariate ENSO Index (MEI), Oceanic Nino Index (ONI), serta Dipole Mode Index (DMI). Analisis data pendukung lainnya seperti curah hujan dan temperatur permukaan laut dilakukan untuk memastikan keabsahan data yang digunakan.

\section{METODE PENELITIAN}

\subsection{Deskripsi Lokasi Penelitian}

Secara geografis, Teluk Jakarta terletak antara $5^{\circ} 22^{\prime} 11^{\prime \prime}-5^{\circ} 08^{\prime} 42^{\prime \prime}$ LS dan $106^{\circ} 39^{\prime}-107^{\circ} 03^{\prime}$ BT. Batas geografis Teluk Jakarta di sebelah utara adalah Kepulauan Seribu, sebelah timur adalah Tanjung Karawang, sebelah selatan adalah bagian darat Provinsi DKI Jakarta, dan sebelah barat adalah Tanjung Pasir. Luas wilayah perairan Teluk Jakarta adalah sekitar $514 \mathrm{~km}^{2}$, dengan lebar terbesar adalah $40 \mathrm{~km}$ dan jarak lurus dari Tanjung Karawang ke dataran Jakarta lebih dari $15 \mathrm{~km}$. Perairan Teluk Jakarta cenderung dangkal, dengan kedalaman rataratanya mencapai $15 \mathrm{~m}$. Teluk ini menjadi muara 13 sungai yang melewati Kota Jakarta.

Kondisi perairan Teluk Jakarta telah terpengaruh oleh keberadaan input massa air dari sungai-sungai sekitarnya, hal tersebut didukung oleh penelitian Pusat Penelitian dan Pengembangan Geologi Kelautan (P3GL) tahun 2010 yang membuktikan dengan metode seismik bahwa formasi endapan sedimen dangkal di Teluk Jakarta pada umur skala resen merupakan percampuran endapan deltaik Citarum dengan endapan sedimen 
Laut Dangkal, dimana penyusun dominan endapan Teluk Jakarta adalah endapan deltaik Citarum (Rahardiawan et al., 2016).

Input air tawar dari Citarum tentu dipengaruhi oleh curah hujan yang terjadi di sekitar aliran sungainya. Curah hujan yang tinggi akan menyebabkan semakin besar debit yang akan dialirkan ke hilir sungai Citarum yang berada di Teluk Jakarta yaitu Muara Gembong (Astawa, 2010). Muara Gembong berada di sebelah timur Teluk Jakarta, tepatnya di Kabupaten Bekasi, Jawa Barat. Dengan kondisi material sedimen utama yang berasal dari aliran sungai Citarum, tentu sedimen yang terekam akan banyak dipengaruhi oleh input sungai tersebut. Pengolahan data sedimen selanjutnya akan digunakan untuk menganalisis karakter oseanografi Teluk Jakarta serta kondisi iklim yang mempengaruhi perairan tersebut.

Daerah muara sungai, yang merupakan pertemuan massa air dari sungai dan dari laut, merupakan daerah yang diketahui meng-akibatkan partikel dan material terlarut yang diangkut melalui sungai terjebak hingga kemudian mengendap (Martin et al., 1981). Sedimen yang terendapkan merupakan hasil dari flokulasi material-material yang dibawa oleh sungai dan membutuhkan salinitas tertentu agar terendapkan (Boggs, 2006). Selain itu, pengaruh arus dari maupun ke arah hulu sungai mengakibatkan partikel-partikel dan substansi lain yang bersumber dari sungai dan laut terjebak diantaranya hingga akhirnya mengendap (Goldberg et al., 1979).

\subsection{Bahan dan Data}

Data primer yang diolah dalam penelitian ini adalah sampel sedimen dasar dari perairan Teluk Jakarta, dengan nomor GM01-2010-TJ22, yang diambil pada tahun 2010 oleh PPPGL pada kedalaman $8 \mathrm{~m}$. Sampel yang diteliti merupakan cuplikan dari kedalaman core $0-15 \mathrm{~cm}$ dengan interval 1 $\mathrm{cm}$. Lokasi sampel dapat dilihat pada Gambar 1.
Data sekunder yang digunakan adalah informasi kecepatan pengendapan sedimen GM01-2010-TJ22 yang telah diteliti oleh P3GL pada tahun 2010. Setelah dilakukan pengumuran dengan menggunakan ${ }^{14} \mathrm{C}$, sampel sedimen diketahui memiliki kecepatan sedimentasi 1,67 cm/tahun. Kondisi tersebut didapat dengan anggapan bahwa kedalaman $0 \mathrm{~cm}$ pada core tertanggal 2010 dan kedalaman $100 \mathrm{~cm}$ tertanggal 1950 (Zuraida et al., 2016). Umur sedimen setiap cuplikan dapat dihitung dari kecepatan sedimentasi dan ketebalan sedimen.

Indeks variabilitas iklim antar tahun yang digunakan untuk data tahun 2001-2010 adalah Dipole Mode Index (DMI) yang terjadi di Samudra Hindia dan dirujuk dari https://wwwesrl.noaa.gov/psd/gcos_wgsp/Ti meseries/Data/dmi.long.data dengan interval waktu bulanan. Indeks bulanan Multivariate Enso Index (MEI) diunduh dari tautan https://www.esrl.noaa.gov/psd/enso/mei.ext/t able.ext.html dan Oceanic Nino Index (ONI) dari tautan https://www.esrl.noaa.gov/psd/ data/correlation/oni.data.

Untuk melihat pengaruh musim digunakan data AUSMI yang diunduh dengan interval waktu tahunan dari tautan http://apdrc.

soest.hawaii.edu/projects/monsoon/wnpmidx/ wnpmidx-jjas.txt. Data verifikasi parameter temperatur permukaan laut rata-rata bulanan diperoleh dari citra satelit yang terletak di sekitar titik pengambilan sampel pada tahun 2001-2010 yang diunduh dari tautan https://oceancolor.gsfc.nasa.gov/data/aqua/.

Informasi curah hujan bulanan tahun 2003-2010 diperoleh dari Kabupaten Bekasi Dalam Angka. Lokasi stasiun curah hujan dapat dilihat pada Gambar 1, dan data citra satelit Spot 6 yang didapatkan dari Dinas Lingkungan Hidup Provinsi Jawa Barat.

\subsection{Analisis Data}

Analisis data penelitian ini menggunakan tiga tahapan metode. Metode pertama yang meliputi metode pengolahan sampel sedimen dasar yang sudah diambil 
pada tahun 2010 dan disimpan pasca pengambilan di Laboratorium Penyimpanan Contoh Inti P3GL Cirebon. Sebelum dilakukan analisis besar butir, sampel dipreparasi untuk menghilangkan sisa cangkang hewani dan bahan organik lainnya menggunakan $\mathrm{H}_{2} \mathrm{O}_{2} 20 \%$ dan $\mathrm{HCL} 30 \%$. Hal tersebut dilakukan agar butiran yang dianalisis adalah fragmen litik (batuan) atau mineral.
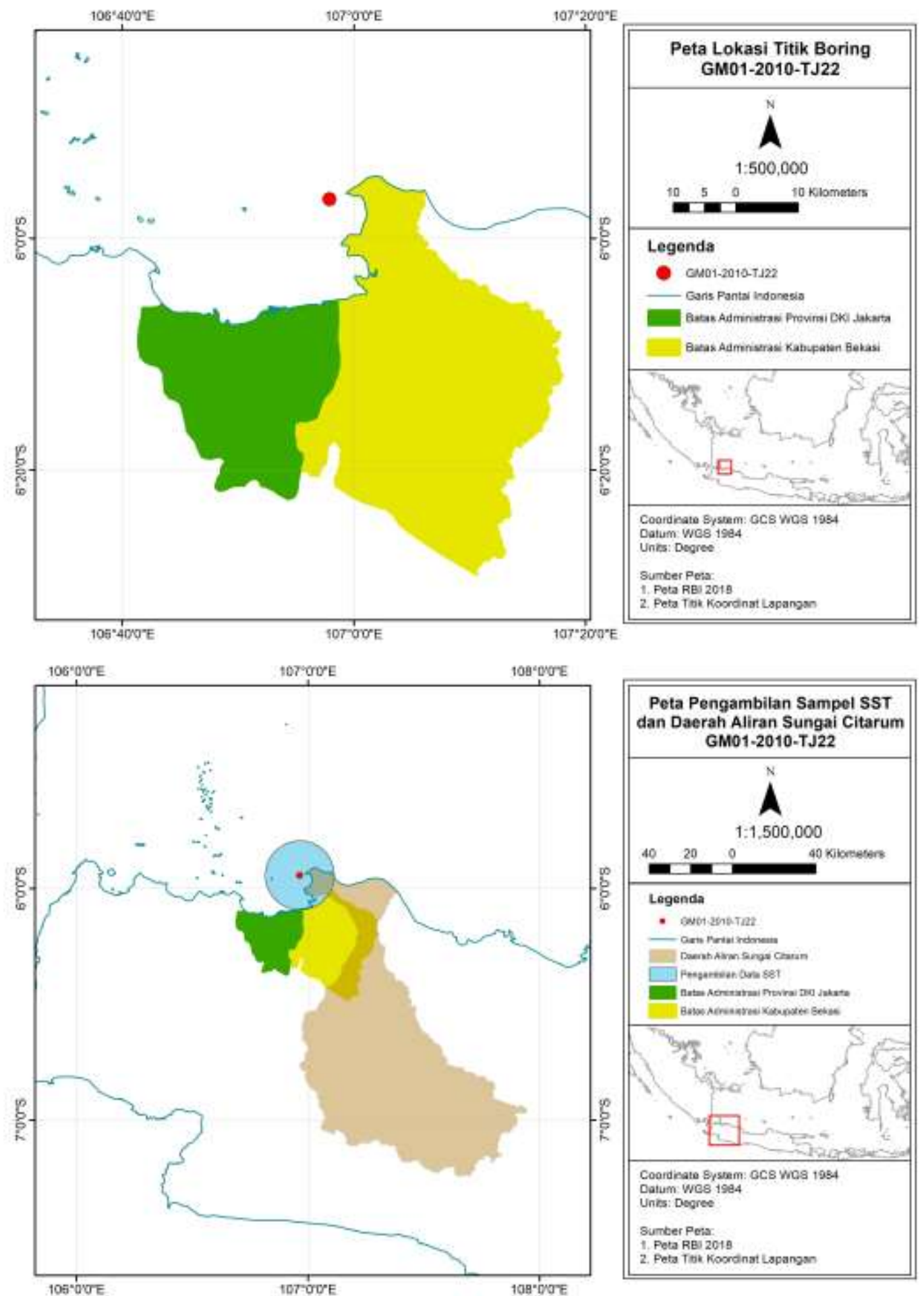

Gambar 1. Peta lokasi pengambilan sampel GM01-2010-TJ22 di Teluk Jakarta (atas) dan Peta DAS Citarum serta Radius data SST yang dicuplik (bawah). 
Selanjutnya dilakukan pengolahan sampel sedimen yang sudah dipreparasi menggunakan alat Laser Particle Analyzer jenis Mastersizer 2000 di Pusat Penelitian Geoteknologi (Puslit Geotek), Lembaga Ilmu dan Pengetahuan Indonesia, Bandung. Pengolahan hasil analisis alat Mastersizer 2000 menggunakan aplikasi Gradistat yang dikembangkan oleh Blott dan Pye (2011) untuk mendapatkan nilai besar butir masingmasing kelompok butir dan nilai besar butir rata-rata per cuplikan. Komponen statistik diolah dengan dua metode mum yaitu metode momen dan metode grafis dari Folk and Ward (1957). Hasil pengolahan ditampilkan dalam satuan $\phi$ yang merupakan nilai $-\log _{2}(d)$ dengan $d$ adalah diameter butir (Boggs, 2006). Uraian formula statistik yang digunakan dalam perhitungan parameter besar butir dapat dirujuk dari Krumbein and Pettijohn (1938) dalam Blott and Pye (2001) dan Folk and Ward (1957) dalam Blott and Pye (2001).

Hasil pengolahan data ukuran besar butir selanjutnya dikorelasikan secara statistik dengan indeks variabilitas iklim musiman AUSMI dan antar tahun DMI, MEI, dan ONI dengan interval bulanan untuk melihat variabilitas iklim yang mempengaruhi kondisi Oseanografi di daerah kajian pada rentang tahun 2001-2010.

Data temperatur muka laut dicuplik menggunakan aplikasi Seadas pada koordinat lintang $-5,93^{\circ} \mathrm{LS}$ dan $106,97^{\circ} \mathrm{BT}$ dengan interval waktu bulanan dari tahun 2001 hingga 2010. Data curah hujan pada stasiun Kabupaten Bekasi dibandingkan dengan data ukuran besar butir. Pengolahan data citra satelit Spot 6 menggunakan aplikasi sistem informasi.

\section{HASIL DAN PEMBAHASAN}

\subsection{Hasil Pengolahan Data Besar Butir}

Hasil pengolahan besar butir sedimen menggunakan Gradistat (Blott dan Pye, 2011) memberikan nilai besar butir rata-rata, dan persentase kandungan masing-masing kelompok butir. Kelompok butir yang secara umum digunakan adalah kerikil (-2 hingga $1 \phi)$, pasir (-1 hingga $4 \phi)$, lanau (4-8 8 ) dan lempung $(8-14 \phi)$ mengikuti skala besar butir Udden Wentworth (Blair and McPherson, 1999). Data besar butir rata-rata dan persentase kandungan kelompok butir penyusun sedimen kemudian diplot terhadap umur yang didapatkan dari Zuraida et al. (2016) untuk mengetahui perubahan ukuran butir dari waktu ke waktu.

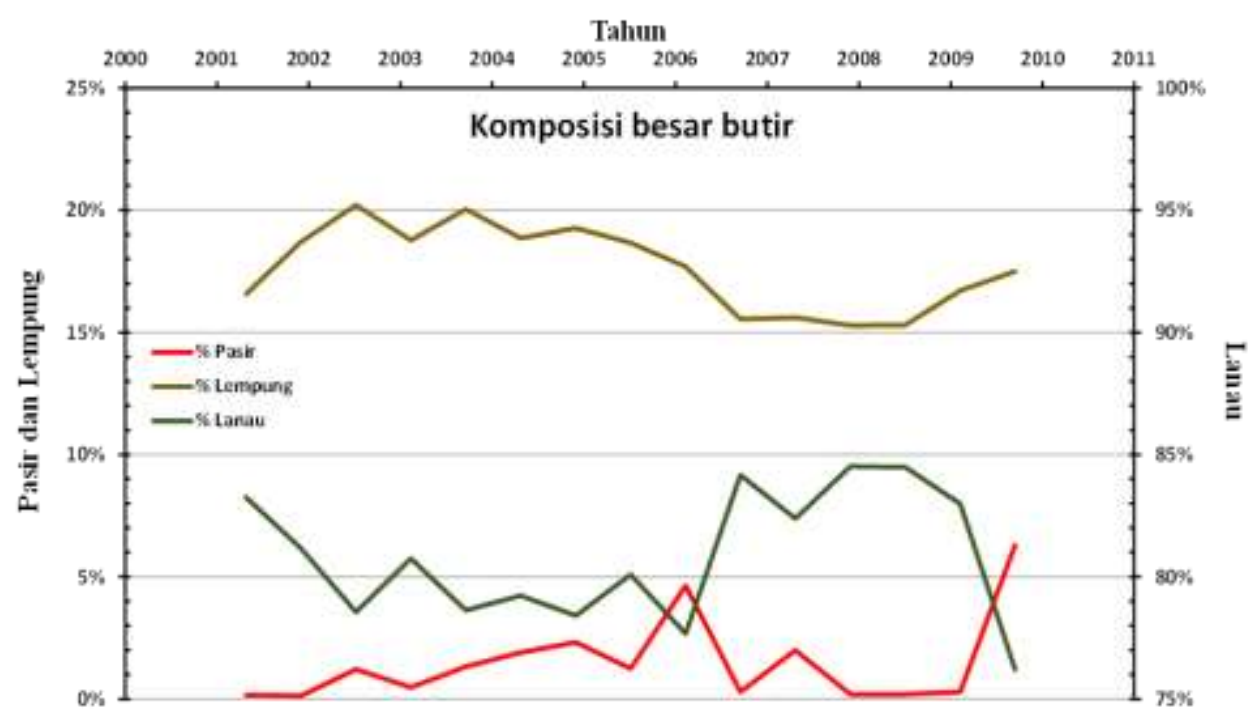


Kajian Statistik Ukuran Besar Butir . . .
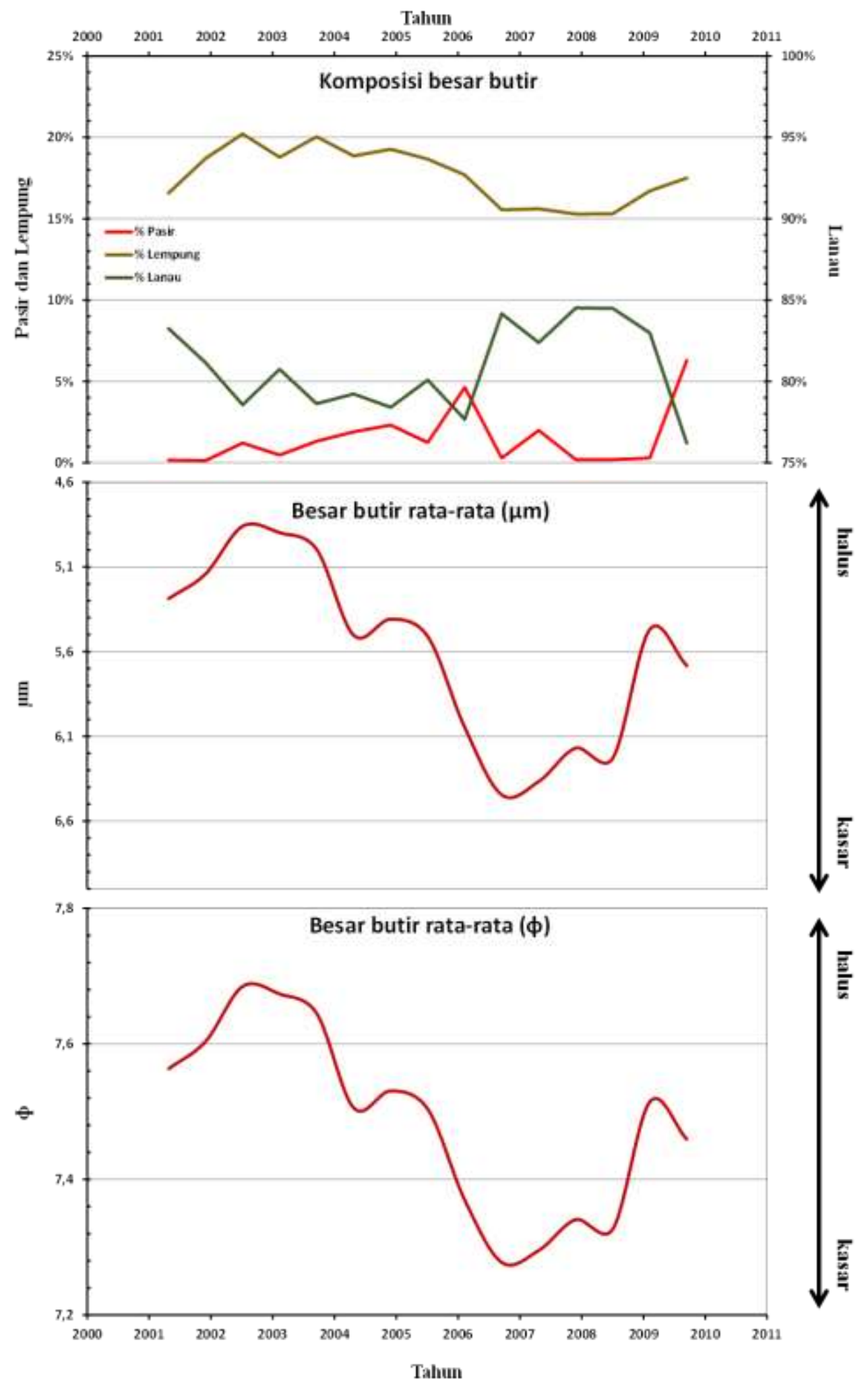

Gambar 2. Ukuran butir rata-rata dalam satuan $\phi$ dan $\mu \mathrm{m}$ dan komposisi masing-masing kelompok ukuran butir sedimen core GM01-2010-TJ22. 
Perbandingan antara ukuran butir ratarata dan komposisi butir (pasir, lanau dan lempung) memperlihatkan bahwa sedimen core GM01-2-10-TJ22 didominasi oleh butiran berukuran lanau (Gambar 2). Grafik menunjukan perubahan besar butir rata-rata sejak 2001 yang dapat dibagi menjadi dua periode: (1) 2001-2005 dengan besar butir yang relatif halus; dan (2) 2005-2010 dengan besar butir rata-rata yang relatif kasar. Kedua periode tersebut juga ditunjukkan oleh perubahan kandungan lanau dalam sedimen.

\subsection{Verifikasi Data Temperatur Permukaan Laut}

Data temperatur permukaan laut digunakan untuk mengetahui hubungan variabilitas iklim terhadap kondisi perairan di sekitar Muara Gembong. Variabilitas iklim yang terjadi tentu mempengaruhi dinamika temperatur permukaan laut di sekitar lokasi pengambilan sampel. Menurut Kida dan Richards (2009 dalam Martono, 2016) untuk mengetahui pola variabilitas iklim yang terjadi di daerah tropis seperti Indonesia dibutuhkan analisis mengenai perubahan musiman dari temperatur permukaan laut atau sea surface temperature (SST).

Selain akibat interaksi laut-atmosfer, perubahan temperatur permukaan laut dapat diakibatkan oleh volume massa air yang masuk dari sungai di sekitarnya, terutama di wilayah perairan dalam teluk (Howden and Murtugudde, 2001). Pada penelitian ini data temperatur permukaan laut sekitar lokasi pengambilan sampel sedimen di Muara Gembong dibandingkan dengan pola besar butir sampel sedimen Muara Gembong. Terlihat dari Gambar 3 bahwa pada periode 2005 hingga 2010 terdapat kesamaan pola waktu dan nilai. Periode 2001 hingga 2005 menunjukkan kesamaan pola nilai namun pola yang dihasilkan memiliki jangka waktu berbeda sehingga nilai temperatur permukaan laut terjadi terlebih dahulu sebelum pola nilai besar butir.

\begin{abstract}
Berdasarkan uji statistik, nilai koefisien korelasi untuk temperatur permukaan laut dengan nilai besar butir di Muara Gembong tahun 2001-2010 memiliki koefisien korelasi sebesar 0,746 . Uji hipotesis pada kedua variabel tersebut menghasilkan nilai besar butir, sehingga memiliki korelasi signifikan dengan temperatur permukaan laut dengan nilai $\mathrm{T}_{\text {hitung }}$ sebesar 4,036 dan $\mathrm{T}_{\text {tabel }}$ sebesar 3,372. Korelasi yang dihasilkan pada kedua varibel saling berbanding lurus, hal tersebut menunjukkan nilai temperatur yang tinggi akan diikuti dengan besar butir yang semakin halus, begitu pula sebaliknya.
\end{abstract}

\subsection{Verifikasi Data Curah Hujan}

Data besar butir juga dibandingkan dengan curah hujan di sekitar hilir, selain dibandingkan dengan temperatur permukaan laut. Data curah hujan yang digunakan sebagai pembanding curah hujan di hilir Sungai Citarum adalah data curah hujan Kabupaten Bekasi. Data tersebut didapat dari Kabupaten Bekasi Dalam Angka 2004-2011. Data curah hujan Kabupaten Bekasi diambil karena Muara Gembong berada di wilayah Kabupaten Bekasi. Diagram curah hujan Kabupaten Bekasi yang terlihat pada Gambar 4 merupakan data curah hujan rata-rata tahunan Kabupaten Bekasi.

Perhitungan korelasi nilai besar butir rata-rata dengan curah hujan Kabupaten Bekasi menghasilkan nilai untuk interval waktu 2004 hingga 2010 adalah -0,022,

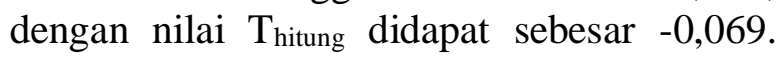
Pada Gambar 3 terlihat pola yang dihasilkan kedua data tidak konsisten. Pada interval waktu 2004-2005 dan 2009-2010 kedua data saling berbanding lurus, sedangkan pada interval 2005-2008 kedua data saling berbanding terbalik.

Curah hujan sangat mempengaruhi volume air sungai yang juga akan berpengaruh terhadap besar butir yang tertransport oleh sungai. Fenomena ini diamati oleh Cao et al. (2012) pada sedimen berumur Holosen dari estuari Pearl River. Perbandingan nilai besar butir dengan data 
curah hujan Kabupaten Bekasi pada interval waktu tahun 2005-2009 menunjukkan pola yang sama. Perhitungan koefisien korelasi untuk kedua data dalam interval waktu 2005-

2009 menghasilkan koefisien korelasi sebesar $-0,753$ dan nilai $\mathrm{T}_{\text {hitung }}$ sebesar $-2,807$ dengan $\mathrm{T}_{\text {tabel }}$ sebesar 2,447.

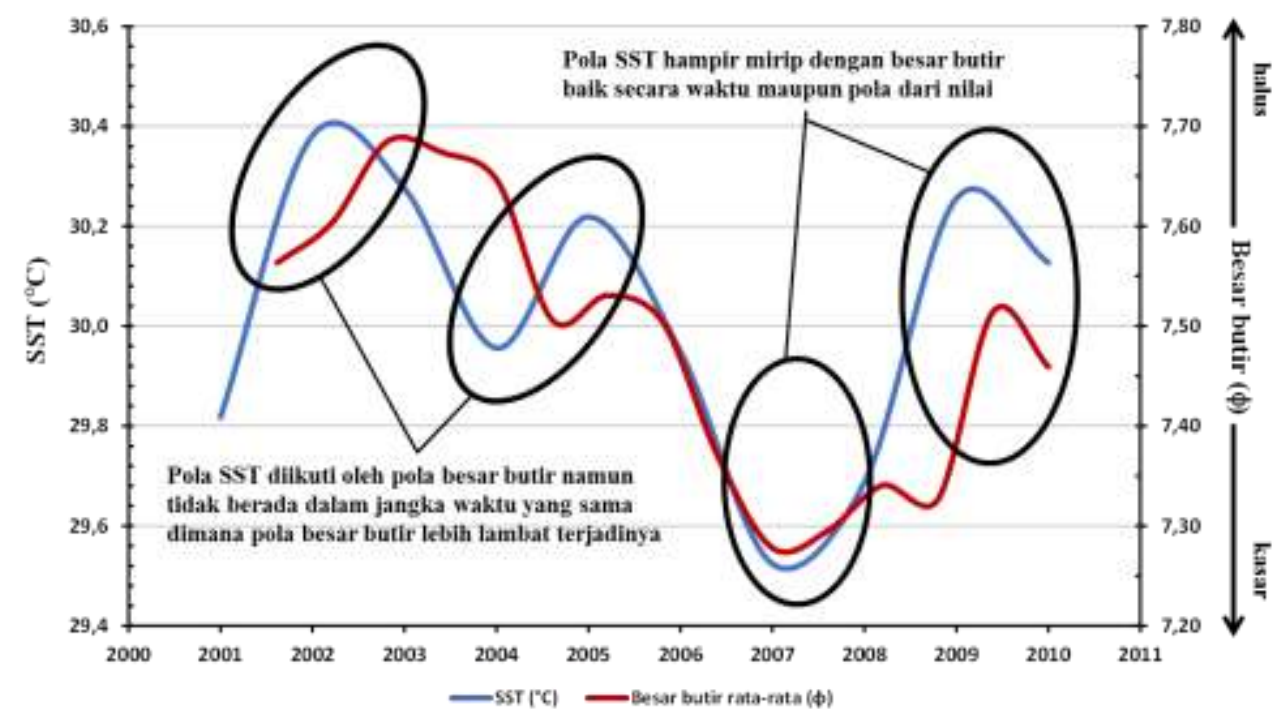

Gambar 3. Diagram temperatur permukaan laut rata-rata interval tahunan di sekitar titik pengambilan sampel sedimen yang dibandingkan dengan data rata-rata besar butir dari tahun 2001 hingga 2010.

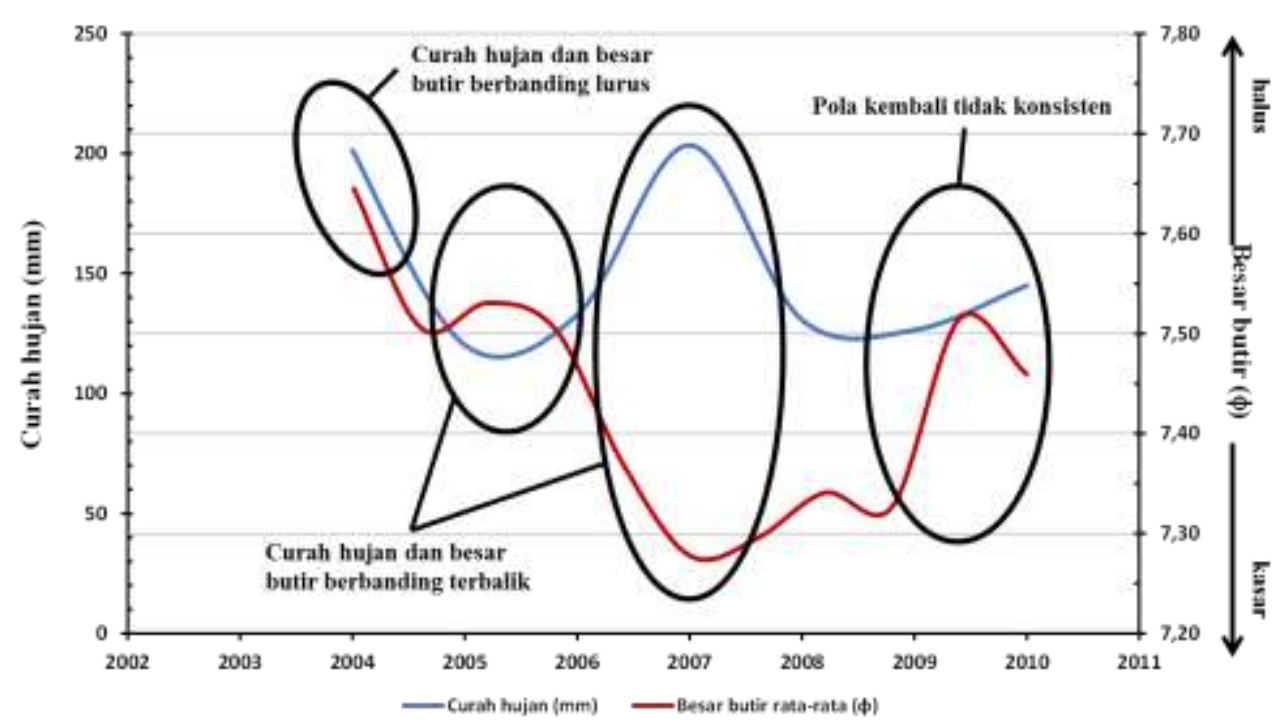

Gambar 4. Diagram curah hujan Kabupaten Bekasi (dekat hilir Citarum) yang dibandingkan dengan data tahunan rata-rata besar butir dari tahun 2004 hingga 2010.

\subsection{Korelasi Analisis Besar Butir dengan Australian Summer Monsoon}

Menurut Kajikawa et al. (2009), perubahan perlahan angin timur ke baratan di daerah kajian monsun terjadi pada awal Desember dan berbalik lagi pada pertengahan 
Maret, selang waktu tersebut merupakan kondisi AUSMI dimana antara bulan Desember hingga Februari terjadi peningkatan curah hujan dari bulan-bulan sebelumnya. Indeks AUSMI antar tahun secara umum berkaitan erat dengan ENSO, dimana monsun lemah terjadi saat El Niño dan monsun kuat terjadi pada saat kondisi $L a$ Niña. Selain pada curah hujan, variasi AUSMI juga dipengaruhi oleh durasi musim hujan. Kondisi musim hujan yang direpresentasikan dalam indeks AUSMI beserta komponen yang mempengaruhinya serupa dengan kondisi di Indonesia. Musim hujan di Indonesia dipengaruhi oleh pola angin dan kondisi ENSO serta waktu puncak terjadinya musim hujan, yaitu interval bulan DJF (Desember-Januari-Februari).
Pada Gambar 5 secara umum terlihat bahwa tren besar butir dan AUSMI berbanding terbalik. Kondisi tersebut terlihat jelas pada interval waktu tahun 2001 hingga 2006 serta 2009 hingga 2010. Anomali terjadi pada sekitar tahun 2007, dimana tren besar butir berbanding lurus dengan tren AUSMI. Periode 2001 hingga 2007 terlihat pula jika nilai masing-masing varibel cenderung menurun, dengan puncaknya terjadi pada periode 2007 (saat periode 2007, AUSMI menunjukan angka $-1,287$, terendah dari interval waktu 2001-2007). Pada periode 2007-2008, AUSMI menggambarkan perubahan nilai yang paling drastis, yaitu pada nilai $-1,287$ menuju 0,999, namun perubahan drastis tersebut tidak terekam oleh nilai besar butir pada periode yang sama.

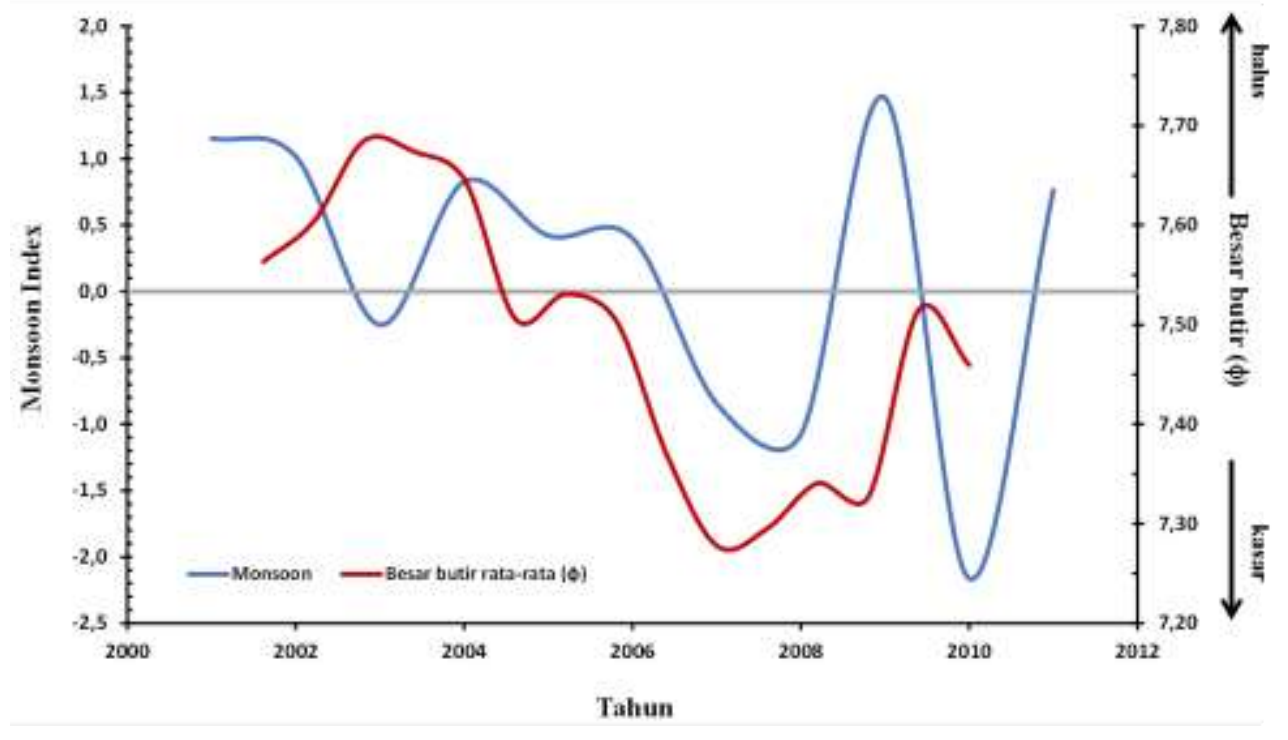

Gambar 5. Diagram besar butir rata-rata yang dibandingkan dengan data tahunan Australian Monsoon Index dari tahun 2000 hingga 2010.

\subsection{Korelasi Analisis Besar Butir dengan Multivariate ENSO Index (MEI)}

Perbandingan grafik besar butir ratarata dengan MEI (Multivariate Enso Index) terlihat pada Gambar 6. Terdapat pola-pola yang sama pada grafik tersebut, pada tahun 2001 hingga 2006 awal pola MEI dan besar butir rata-rata memiliki pola yang sama. Meskipun terdapat anomali pada grafik namun pola besar butir rata-rata mendahului pola MEI. Tahun 2007 awal terjadi ketimpangan ekstrim secara grafik, dimana MEI berangsur ke arah indeks positif sedangkan rata-rata besar butir menurun ke titik sekitar 10.79 dari titik terakhir (sekitar pertengahan tahun 2006). Anomali tersebut memperlihatkan bahwa pada periode 2007 nilai besar butir tidak menggambarkan kondisi ENSO yang terjadi, jika merujuk pada pola yang dihasilkan periode lainnya pada interval waktu 2001-2010. 
MEI sendiri merupakan sebuah indeks yang menggambarkan kondisi ENSO berdasarkan enam parameter berbeda; tekanan muka air, angin permukaan zonal dan meridian, temperatur permukaan air, temperatur permukaan udara dan persebaran awan. Pada diagram MEI, terdapat dua jenis indeks yang masing-masing mengindikasikan kejadian berbeda. Indeks positif mengindikasikan fase panas dari ENSO atau disebut juga dengan $\mathrm{El}$ Niño dan indeks negatif mengindikasikan fase dingin dari ENSO atau disebut juga dengan La Niña.

Secara umum pada diagram, fase positif atau El Niño pada grafik data MEI diikuti dengan nilai $\phi$ dari besar butir yang lebih besar, atau diikuti dengan rata-rata besar butir yang lebih halus. Kondisi tersebut mengindikasikan bahwa fase El Niño mengakibatkan minimnya input air tawar dari Citarum yang mengakibatkan butiran yang lebih kasar tidak terbawa oleh arus sungai. Sebaliknya, pada fase La Niña atau ketika nilai MEI berada di bawah nol, kondisi tersebut diikuti dengan nilai $\phi$ yang lebih kecil atau rata-rata besar butir yang lebih besar, artinya input air sungai yang tinggi karena arus yang terekam tinggi sebagai penggambaran tak langsung dari butiran silika yang lebih kasar.

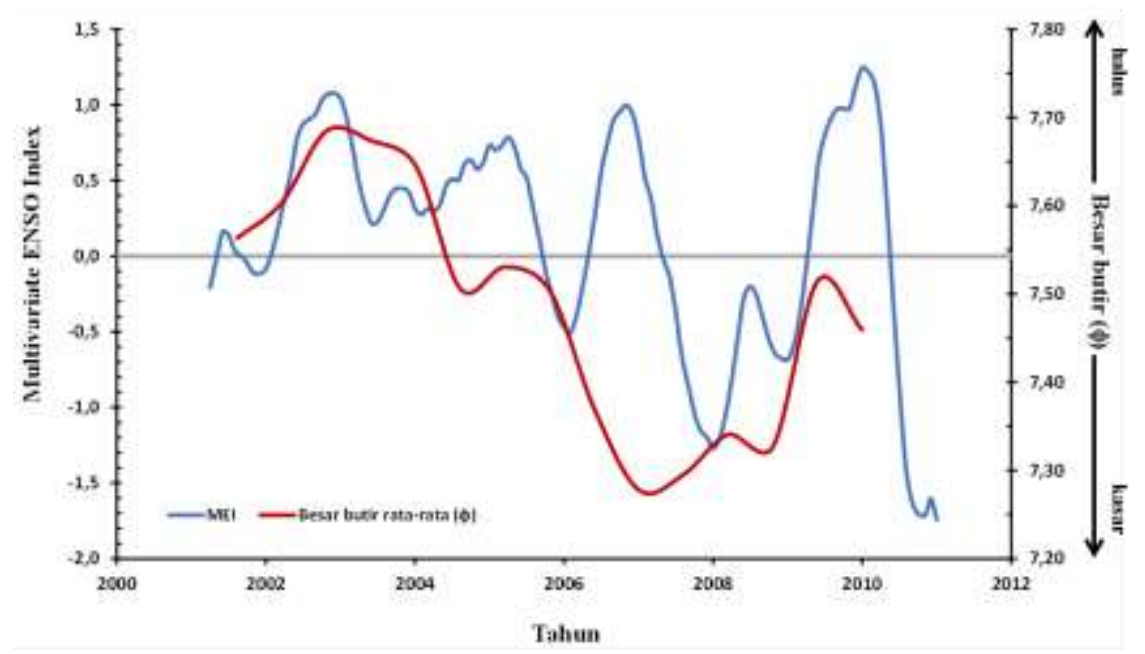

Gambar 6. Diagram besar butir rata-rata yang dibandingkan dengan data bulanan Multivariate ENSO Index(MEI) dari tahun 2001 hingga 2010.

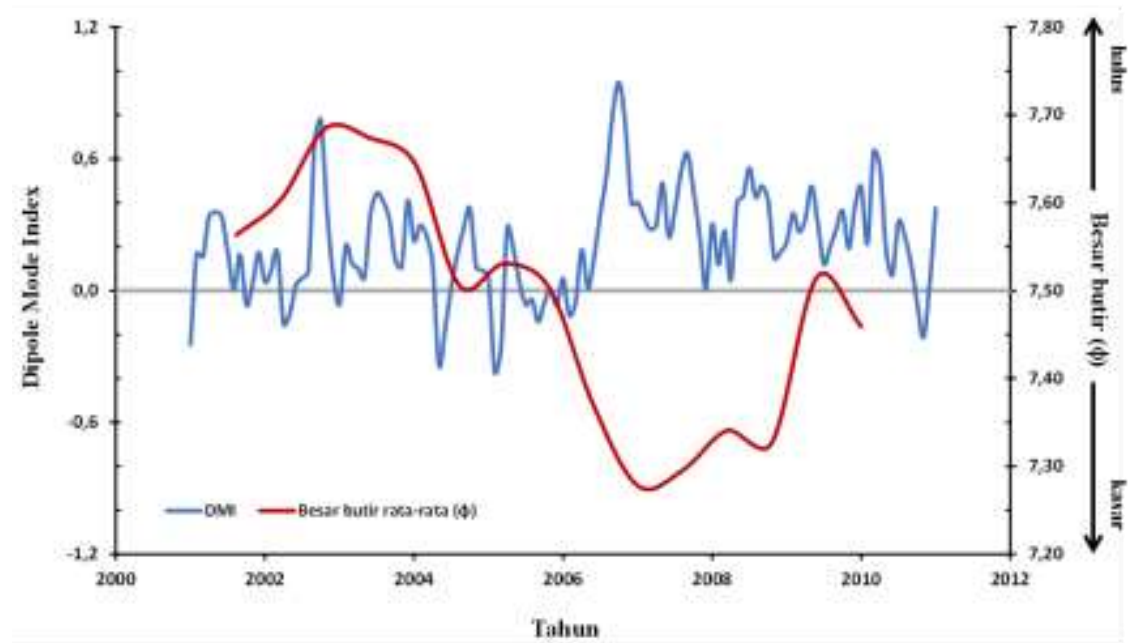

Gambar 7. Diagram besar butir rata-rata yang dibandingkan dengan data bulanan Dipole Mode Index dari tahun 2001 hingga 2010. 


\subsection{Korelasi Analisis Besar Butir dengan Dipole Mode Index (DMI)} Dipole Mode Index (DMI) mengindikasikan pola panas-dingin dari perbedaan temperatur permukaan laut antara Samudera Hindia sebelah barat dan timur. Seperti halnya fenomena ENSO, Indian Ocean Dipole juga mempengrauhi kondisi iklim di Indonesia (Mulyana, 2002). Indeks positif pada DMI mengindikasikan kondisi nilai temperatur permukaan laut dan presipitasi di sebelah barat Samudera Hindia lebih besar dari rata-rata, sedangkan kondisi temperatur pemukaan laut dan presipitasi di sebelah timur Samudera Hindia lebih rendah dari rata-rata, yang dapat mengakibatkan terjadinya kekeringan di sekitar Indonesia. Kondisi sebaliknya terjadi pada IOD negatif atau indeks negatif pada DMI. Hal tersebut menggambarkan kondisi temperatur permukaan laut dan presipitasi di sebelah barat Samudera Hindia yang lebih rendah dari rata-rata, disamping itu bersamaan dengan lebih tingginya temperatur permukaan laut dan presipitasi di sebelah timur Samudera Hindia, sehingga mengakibatkan naiknya curah hujan di sekitar Indonesia.

Terlihat pada Gambar 7, pola yang dihasilkan nilai besar butir dan DMI tidak begitu mirip, jika dibandingkan dengan pola yang dihasilkan oleh nilai besar butir dan MEI. Dua data seri waktu tersebut juga tidak menunjukkan pola berbanding terbalik atau berbanding lurus yang jelas. Puncak nilai besar butir pada sekitaran tahun 2003 diikuti dengan nilai kedua tertinggi dari DMI. Sedangkan pada periode 2007, nilai besar butir dan DMI berbanding terbalik. Anomali pada tahun 2007 terlihat dengan nilai besar butir berbanding terbalik dengan indeks DMI, hal tersebut sama seperti kondisi yang tergambarkan pada grafik nilai besar butir terhadap MEI sehingga mengindikasikan bahwa nilai besar butir pada periode 2007 tidak dapat menggambarkan kondisi Dipole Mode. Pola yang terjadi tidak konsisten dengan pola yang sering terjadi pada interval waktu 2001-2010.

\subsection{Uji Statistik Nilai Besar Butir dengan Indeks Musim dan Antar Tahun}

Berdasarkan perhitungan koefisien korelasi antara nilai besar butir dengan nilai masing-masing dari MEI, DMI dan AUSMI, diperoleh hasil 0,455 untuk koefisien korelasi besar butir terhadap MEI, dan 0,345 untuk koefisien besar butir terhadap DMI. Sedangkan untuk koefisien korelasi besar butir terhadap AUSMI diperoleh hasil -0,437 dengan perhitungan koefisien korelasi untuk nilai besar butir dan indeks variabilitas iklim pada rentang tahun 2001-2010 (Tabel 1). Korelasi antara besar butir dan MEI adalah yang terkuat dibandingkan dengan korelasi nilai besar butir dengan DMI dan AUSMI. Perhitungan koefisien korelasi tersebut didapatkan tanpa merubah fase masingmasing variabel, adanya pengubahan fase dari variabel terkait dapat meningkatkan nilai koefisien korelasi yang didapat.

Tabel 1. Korelasi Statistika Nilai Besar Butir dengan MEI, ONI, DMI, dan AUSMI.

\begin{tabular}{lccccc}
\hline & $\begin{array}{c}\text { Koefisien } \\
\text { Korelasi }\end{array}$ & $\begin{array}{c}\text { Koefisien } \\
\text { Determinasi }\end{array}$ & $\begin{array}{c}\text { Taraf } \\
\text { Keberartian }\end{array}$ & $\mathrm{T}_{\text {hitung }}$ & $\mathrm{T}_{\text {tabel }}$ \\
\hline MEI & 0,455 & 0,207 & $95 \%$ & 5,085 & 1,984 \\
ONI & 0,472 & 0,223 & $95 \%$ & 5,331 & 1,984 \\
DMI & $-0,345$ & 0,119 & $95 \%$ & $-3,662$ & 1,984 \\
AUSMI & 0,437 & 0,191 & $95 \%$ & 6,327 & 2,160 \\
\hline
\end{tabular}

Berdasarkan tiga variabel yang diantaranya memiliki tren yang mendekati dikorelasikan dengan data besar butir, dua pola nilai besar butir, yaitu variabel MEI dan 
AUSMI. Namun, ketiga data seri waktu yang ada tidak dapat menjawab anomali yang terjadi pada periode 2007, karena nilai besar butir memiliki poin terendah yang mengindikasikan semakin kasarnya butiran yang teranalisis. Kekasaran tersebut seharusnya diiringi dengan tingginya curah hujan yang terjadi di sekitar DAS Citarum, dan ketiga data menunjukan fase kekeringan pada periode tersebut. Kondisi tersebut mungkin terjawab jika fase dari nilai besar butir diubah mengikuti fase dari AUSMI.

Uji hipotesis dilakukan berdasarkan nilai $\mathrm{T}$ yang dihitung melalui nilai korelasi dua variable. Indeks MEI, ONI, DMI dan AUSMI berkorelasi signifikan dengan nilai besar butir pada periode tersebut, terlihat pada Tabel 1 dan Gambar 8 nilai $T_{\text {hitung }}$ semua indeks berada dalam rentang penolakan $\mathrm{H}_{0}$. Perhitungan tersebut menggunakan taraf signifikansi 5\%, dan diperkirakan kurang dari 5\% data yang digunakan dalam perhitungan memiliki kesalahan pengukuran. Sehingga hubungan MEI, ONI, DMI dan AUSMI dengan nilai besar butir adalah berkorelasi signifikan.
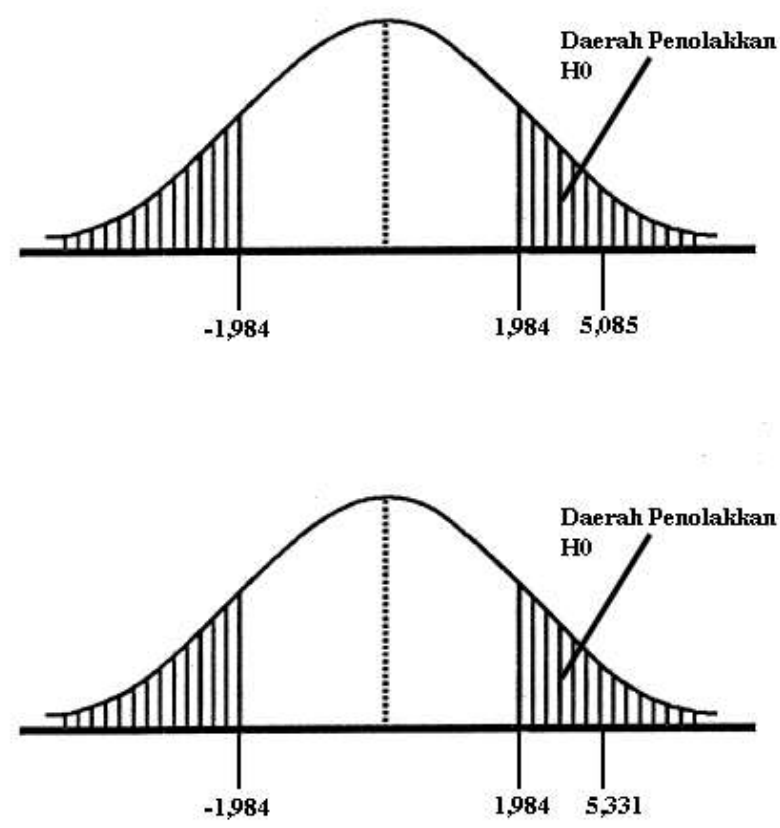
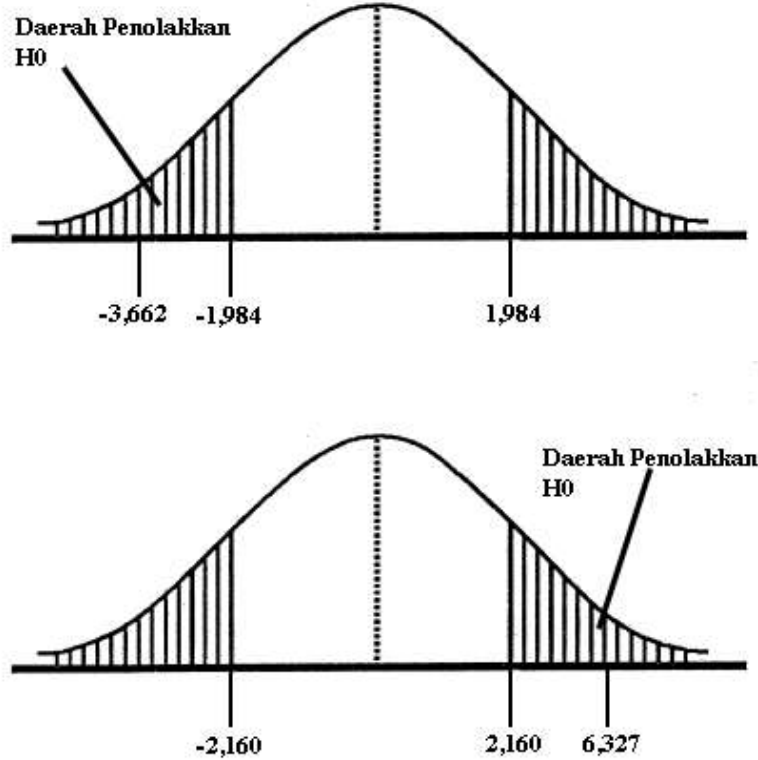

Gambar 8. Diagram sebaran data statistik untuk uji hipotesis korelasi signifikan antara nilai besar butir dengan data MEI tahun 2001-2010 (kiri atas), ONI tahun 2001-2010 (kiri bawah), DMI tahun 2001-2010 (kanan atas) dan AUSMI tahun 2001-2010 (kanan bawah).

\section{KESIMPULAN}

Uji statistik dilakukan pada nilai besar butir sedimen rata-rata terhadap pengaruh monsun dan fenomena antara tahun. Analisis korelasi nilai besar butir terhadap temperatur permukaan laut dan curah hujan dilakukan untuk mengetahui keabsahan data. Nilai besar butir menunjukkan korelasi positif yang signifikan terhadap temperatur permukaan laut. Nilai besar butir sampel sedimen Muara Gembong memiliki korelasi signifikan dengan curah hujan Kabupaten Bekasi untuk periode 2005-2009. Kedua hasil uji tersebut menunjukkan bahwa curah hujan yang tinggi diikuti dengan menurunnya temperatur permukaan laut dan terjadinya pengendapan material sedimen yang berukuran relatif lebih kasar, sedangkan curah hujan yang rendah 
mengakibatkan semakin tingginya temperatur permukaan laut dan pengendapan sedimen yang berukuran relatif lebih halus.

Nilai besar butir yang dihasilkan dari analisis besar butir sampel sedimen Muara Gembong mengindikasikan bahwa peningkatan curah hujan akibat variabilitas iklim oleh ENSO, dipole mode, dan monsoon diikuti dengan semakin besarnya nilai besar butir sampel sedimen Muara Gembong tahun 2001-2010. Hasil tersebut menunjukkan bahwa data besar butir dari sedimen Teluk Jakarta dapat digunakan untuk mengetahui variabilitas iklim di daerah tersebut.

\section{UCAPAN TERIMA KASIH}

Terima kasih penulis ucapkan kepada Pusat Penelitian dan Pengembangan Geologi Kelautan, Kementrian Energi dan Sumber Daya Mineral atas penggunaan data sampel sedimen GM01-2010-TJ22, Laboratorium Geoteknologi Lembaga Ilmu dan Pengetahuan Indonesia atas bantuan penggunaan fasilitas pengolahan data Mastersizer 2000 serta Laboratorium Paleontologi, Teknik Geologi, Fakultas Ilmu dan Teknologi Kebumian, Institut Teknologi Bandung atas bantuan dalam preparasi sampel sedimen.

Data yang tersedia dari NOAA/ESRL,

Physical Sciences Division, Boulder

Colorado diperoleh dari tautan

https://www.esrl.noaa.gov/psd/gcos_wgsp/Ti

meseries/Data/dmi.long.data,

https://www.esrl.noaa.gov/psd/enso/mei.ext/t

able.ext.html, dan

https://www.esrl.noaa.gov/psd/data/correlatio n/oni.data.

Data indeks monsoon oleh Kajikawa dan Wang (2009) tersedia di situs Asia Pacific Data Research Center (APDRC).

\section{DAFTAR PUSTAKA}

Astawa, I.N. 2010. Geologi bawah permukaan dasar laut berdasarkan hasil penafsiran data seismik perairan Teluk Jakarta dan sekitarnya. Buletin Sumber Daya Geologi, 5(1): 10-17.

Blair, T. and J.G. McPherson. 1999. Grainsize and textural classification of coarse sedimentary particles. J. of Sedimentary Research, 69(1): 6-19. https://doi.org/10.2110/jsr.69.6

Blott, S.J. and K. Pye. 2001. Gradistat: a grain size distribution and statistics package for the analysis of unconsolidated sediments. Earth Surface Processes and Landforms, 26(11): 1237-1248.

https://doi.org/10.1002/esp.261

Boggs, S. 2006. Principles of sedimentology and stratigraphy, $4^{\text {th }}$ ed. Pearson Prentice Hall, Pearson Education, Inc., Upper Saddle River, NJ 07458. US. 565pp.

Cao, L., P. Wang, J-H. Wang, X-J. Wang, and J. Yang. 2012. Changes in magnetic susceptibility and grain size of Holocene sediments of the Pearl River estuary and climate changes reflected by them. Marine Science Bulletin, 14(2): 70-82.

Goldberg, E.D., J.J. Griffin, V. Hodge, M. Koide and H. Windom. 1979. Pollution History of the Savannah River Estuary. Environmental Science and Technology, 13(5): 588-594. https://doi.org/10.1021/es60153a012

Howden, S.D., and R. Murtugudde. 2001. Effects of river inputs into The Bay of Bengal. J. of Geophysical Research, 106(C9): 19.825-19.843. https://doi.org/10.1029/2000JC00065 6

Kajikawa, Y., B. Wang dan J. Yang. 2009. A Multi-time Scale Australian Monsoon Index. International J. of Climatology, 30(8): 1114-1120. https://doi.org/10.1002/joc. 1955

Lopez-Gonzalez, N., B. Alonso, C. Juan, G. Ercilla, G. Bozzano, I. Cacho, D. Casas, D. Palomino, J-T Vázquez, F. Estrada, P. Bárcenas, E. d'Acremont, 
C. Gorini and B.E. Moumni. 2019. 133,000 Years of sedimentary record in a contourite drift in the Western Alboran Sea: sediment sources and paleocurrent reconstruction. Geosciences, 9(8): 345. https://doi.org/10.3390/geosciences 90 80345

Martin, J.M., J.D. Burton dan D. Eisma. 1981. River Inputs to Ocean System. United Nation Environment Programme, Geneva, Switzerland.

Martono. 2016. Seasonal and inter annual variation of Sea Surface Temperature in The Indonesian Waters. Forum Geografi, 30(2): 120-129. https://doi.org/10.23917/forgeo.v30i2. 1530

Moechtar, H. 2011. Sedimentologi dan stratifikasi endapan Sungai Citarum di wilayah peralihan morfotologi pegunungan dan dataran tinggi Bandung antara Desa Cikawao dan Desa Nagrak (Kec. Pacet) dan Desa Sukamaju (Kec. Majalaya), Kab. Bandung. J. Geologi dan Sumberdaya Mineral, 21(4): 101-201. http://doi.org/10.33332/jgsm.geologi. 21.4.191-201

Mulyana, E. 2002. Pengaruh dipole mode terhadap curah hujan di Indonesia. $J$. Sains \& Teknologi Modifikasi Cuaca, 3(1): 39-43. http://doi.org/10.29122/jstmc.v3i1.21 58

Prartono, T., H. Razak, and I. Gunawan. 2009. Organochlorine pesticides in the coastal sediment of Citarum estuary, Jakarta Bay: the important role of fine fraction of the sediment as their agent transport and processes of their early diagenesis. J. Ilmu dan Teknologi Kelautan Tropis, 1(2): 11-21. https://doi.org/10.29244/jitkt.v1i2.786 9

Rahardiawan, R., Y.A. Priohandono, F.X.H. Prabowo, R. Zuraida dan Subarsyah. 2016. Pola Pengendapan dan Indikasi Penurunan Sifat Fisik Sedimen di Perairan Teluk Jakarta Berdasarkan Data Set Seismik Single-Channel dan SBP. Puslitbang Geologi Kelautan KESDM. Jakarta, Indonesia: Workshop IAGI (14 Juni 2016).

Zuraida, R., R. Rahardiawan, dan $\mathrm{H}$. Permana. 2016. Historical Record of Heavy Metal of Jakarta Bay Sediment. Lembaga Ilmu Pengetahuan Indonesia, Energi dan Sumberdaya Mineral. Denpasar, Indonesia: SPICE Meeting (20-21 Januari 2016).

Received : 28 August 2018

Reviewed : 25 July 2018

Accepted : 25 November 2019 